$<$ Back to results | 1 of 1

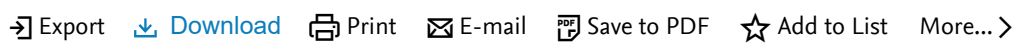

Full Text |View at Publisher|

Document type

Article

Source type

Journal

ISSN

17590833

DOI

10.1108/JIMA-08-2019-0161

View more $\vee$

Journal of Islamic Marketing • Open Access • Volume 12, Issue 7, Pages 1241 - 1259 • 2020

\section{Drivers of Ar-Rahnu (pawn) acceptance: Malaysian evidence}

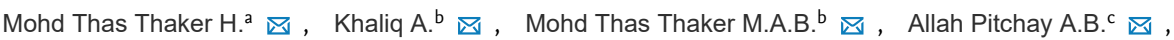

Sakaran K.C. ${ }^{d}$ 函

国 Save all to author list

${ }^{a}$ Department of Economics and Finance, Sunway University, Selangor, Malaysia

${ }^{b}$ Department of Economics and Management Sciences, International Islamic University Malaysia, Kuala Lumpur, Malaysia

${ }^{c}$ Department of Islamic Finance, University Sains Malaysia, Kubang Kerian, Malaysia

${ }^{d}$ Faculty of Business, Economics and Accounting, HELP University, Kuala Lumpur, Malaysia

\section{8}

Views count ?

View all metrics >
Cited by 0 documents

Inform me when this document is cited in Scopus:

Set citation alert >

\section{Related documents \\ Role of ar-rahnu as micro-credit instrument in achieving financial self- sufficiency among women micro- entrepreneurs \\ Nik Azman, N.H. , Kassim, S. , Adeyemi, A.A. \\ (2016) Intellectual Discourse}

Analysing ar-rahnu in the context of informal credit market theory: Evidence from women micro-entrepreneurs in Malaysia

Nik Azman, N.H. , Kassim, S. Adeyemi, A.A.

(2018) ISRA International Journal of Islamic Finance

The non-muslims response towards Ar-Rahnu (Islamic pawn broking) services: An empirical study on the Ar Rahnu clients of Klang Valley, Malaysia Muhamat, A.A., Rosly, H.E. , Jaafar, M.N.

(2011) 2011 IEEE Colloquium on Humanities, Science and Engineering, CHUSER 2011

View all related documents based on references

Find more related documents in Scopus based on:

Authors > Keywords >

Abstract

Author keywords

SciVal Topics

Metrics

Funding details

\title{
Abstract
}

Purpose: The purpose of this paper is to examine the factor persuading the acceptance of Islamic pawn broking (Ar Rahnu ) among Islamic bank customers. Design/methodology/approach: The authors collected the data using a selfadministered questionnaire design and analysed using SPSS Statistics and smart partial least square. The study is restricted to only respondents who are based in the area of Klang Valley (Selangor and Kuala Lumpur), as these two areas have a larger number of Islamic banks and a decent number of Islamic banks' clients. A total of 381 respondents' responses are used for this study, and the constructs involved for analysis purpose are affect, social factor, facilitating conditions, perceived financial benefits and perceived risk constructs. Findings: The finding suggests a significant positive association for social factor and perceived risk, while negative association learnt for affect on acceptance of Ar - Rahnu financing. On the same note, the facilitating condition and perceived financial benefit are found insignificantly related. Practical implications: The findings generated from this study are expected to enrich the literature on the body of knowledge, as it has served to broaden the understanding of the Ar - Rahnu acceptance level in Malaysia. As mentioned, there is limited literature available using this type of financing. Existing studies focus too much on conventional financing products such as personal financing, credit card, short-term loan and many others. Less attention is given to Ar - Rahnu financing. Thus, this study expected to add value to the literature available in the context of Islamic pawn broking business. Moreover, the findings of this study will be very helpful for the Islamic financial institutions to find the best way to retain $\mathrm{Ar}$ - Rahnu clients and encourage more client to choose $\mathrm{Ar}$ - Rahnu as a mode of financing. Originality/value: This study owns greater 
potential to assist Islamic financial institutions to discover the best techniques to retain and encourage the grander number of clients for Ar - Rahnu as a mode of financing. (C) 2020, Emerald Publishing Limited.

\section{Author keywords}

Acceptance; Ar - Rahnu ; Factors

\section{SciVal Topics (i)}

Metrics

Funding details

References (70)

View in search results format $>$

All Export 合Print $\boldsymbol{B}$ E-mail 嵒 Save to PDF Create bibliography

1 Razak, D.A., Abduh, M.

Customers' attitude towards diminishing partnership home financing in Islamic banking (Open Access)

(2012) American Journal of Applied Sciences, 9 (4), pp. 593-599. Cited 36 times.

http://thescipub.com/pdf/10.3844/ajassp.2012.593.599

doi: 10.3844 /ajassp.2012.593.599

View at Publisher

2 Abdul Razak, D.

(2011) Economic and Religious Significance of the Islamic and Conventional Pawnbroking in Malaysia. Cited 5 times.

(Doctor of Philosophy), Durham university, retrieved from

http://etheses.dur.ac.uk/1377/

3 Adnan, M.H.

Pajak Gadai dari Sudut Pengguna

(2004) Paper Presented at the Konvensyen Ar-Rahnu Serantau 2004, organised by the

Regional Ar-Rahnu Secretariat on 26th-31st October 2004

Kuala Lumpur, Malaysia

4 Amin, H., Chong, R.

Determinants for Ar-Rahnu usage intentions: an empirical investigation

(2011) African Journal of Business Management, 5 (20), pp. 8181-8191. Cited 6 times.

5 Amin, H., Chong, R., Dahlan, H., Supinah, R.

An Ar-Rahnu shop acceptance model (ARSAM)

(2007) Labuan e-Journal of Muamalat and Society, 1, pp. 82-94. Cited 12 times.

6 Appannan, S., Doris, G.

A study on Islamic pawn broking awareness and factors influencing the scheme in Sungai Petani, Kedah

(2011) Paper Presented at the Proceedings of the 2nd International Conference on

Business and Economic Research (ICBER). Cited 8 times.

Langkawi, Malaysia

7 Baharum, N.N., Maamor, S., Othman, A.

Examining the factors that influence customer's intention to use Ar-Rahnu at post office: a case study in Kedah

(2015) Journal of Islamic Economics Banking and Finance, 11 (4), pp. 86-99. Cited 3 times. 
8 Bandura, $\mathrm{A}$.

(1986) Social foundations of thought and action: a social cognitive theory. Cited 29205

times.

Prentice-Hall, Inc., Englewood Cliffs, NJ

9 Bauer, $R$.

Consumer behavior as risk taking

(1967) Risk Taking and Information Handling in Consumer Behavior, pp. 21-33. Cited

1095 times.

Cox, D.F. (Ed.), Harvard University Press, Cambridge, MA

10 Bauer, R.A.

(1960) Consumer Behavior as Risk Taking, pp. 384-398. Cited 1095 times.

American Marketing Association, Chicago, IL

11 Bhatt, P., Sinnakkannu, J.

Ar-Rahnu (Islamic pawning broking) opportunities and challenges in Malaysia (2008) Paper Presented at the 6th International Islamic Finance Conference 2008, organised by the Monash University on 13th-14st October 2008

Kuala Lumpur, Malaysia

12 Bock, G.-W., Zmud, R.W., Kim, Y.-G., Lee, J.-N.

Behavioral intention formation in knowledge sharing: Examining the roles of extrinsic motivators, social-psychological forces, and organizational climate

(2005) MIS Quarterly: Management Information Systems, 29 (1), pp. 87-111. Cited 2636

times.

http://misq.org/misq/downloads/

doi: $10.2307 / 25148669$

View at Publisher

13 Caruana, A.

Service loyalty: the effects of service quality and the mediating role of customer satisfaction (2002) Eur. J. Mark, 36 (7-8), pp. 28-811. Cited 736 times.

14 Chang, I.-C., Hwang, H.-G., Hung, W.-F., Li, Y.-C.

Physicians' acceptance of pharmacokinetics-based clinical decision support systems

(2007) Expert Systems with Applications, 33 (2), pp. 296-303. Cited 125 times. doi: 10.1016/j.eswa.2006.05.001

View at Publisher

15 Cheong, C., Sinnakkannu, J.

Ar-Rahnu: opportunities and challenges in Malaysia

(2012) SSRN Electronic Journal

16 Chin, W.W., Marcelin, B.L., Newsted, P.R.

A partial least squares latent variable modeling approach for measuring interaction effects: Results from a Monte Carlo simulation study and an electronic-mail emotion/adoption study

(2003) Information Systems Research, 14 (2), pp. 189-217+218. Cited 3535 times.

http://isr.journal.informs.org/

doi: $10.1287 /$ isre.14.2.189.16018

View at Publisher

17 Cohen, S.

Environmental load and the allocation of attention

(1978) Advances in Environmental Psychology. Cited 190 times.

Baum, A., Singer, J.E. and Valins, S.,(Eds.), Lawrence Erlbaum Associates, Hillsdale, NJ 
18 Cohen, $\mathrm{S}$.

Aftereffects of stress on human performance and social behavior: A review of research and theory

(1980) Psychological Bulletin, 88 (1), pp. 82-108. Cited 498 times.

doi: 10.1037/0033-2909.88.1.82

View at Publisher

19 Echchabi, A., Olaniyi, O.N.

Malaysian consumers' preferences for Islamic banking attributes

(2012) International Journal of Social Economics, 39 (11), pp. 859-874. Cited 25 times. doi: $10.1108 / 03068291211263907$

View at Publisher

20 Featherman, M.S.

Extending the technology acceptance model by inclusion of perceived risk

(2001) Proceedings of the Seventh Americas Conference on Information Systems. Cited 35

times.

Boston, MA

21 Featherman, M.S., Pavlou, P.A.

Predicting e-services adoption: A perceived risk facets perspective (Open Access)

(2003) International Journal of Human Computer Studies, 59 (4), pp. 451-474. Cited 1345

times.

http://www.elsevier.com.ezlib.iium.edu.my/inca/publications/store/6/2/2/8/4/6/index.htt doi: 10.1016/S1071-5819(03)00111-3

View at Publisher

22 Fornell, C., Larcker, D.F.

Structural equation models with unobservable variables and measurement error: algebra and statistics

(1981) Journal of Marketing Research, 18 (3), pp. 382-388. Cited 43003 times.

23 Gold, A.H., Malhotra, A., Segars, A.H.

Knowledge management: An organizational capabilities perspective

(2001) Journal of Management Information Systems, 18 (1), pp. 185-214. Cited 2654

times.

doi: $10.1080 / 07421222.2001 .11045669$

View at Publisher

24 Gujarati, D.N.

(2014) Econometrics by Example. Cited 215 times.

Palgrave Macmillan, New York, NY

25 Hair, J.F., Black, W.C., Babin, B.J., Anderson, R.E., Tatham, R.L.

(2009) Análise Multivariada de Dados. Cited 1941 times.

Bookman Editora

26 Hair, J.F., Hult, G.T.M., Ringle, C.M., Sarstedt, M., Thiele, K.O.

Mirror, mirror on the wall: a comparative evaluation of composite-based structural equation modeling methods (Open Access)

(2017) Journal of the Academy of Marketing Science, 45 (5), pp. 616-632. Cited 447 times. http://www.springer.com.ezlib.iium.edu.my/business/journal/11747

doi: $10.1007 / \mathrm{s} 11747-017-0517-x$

View at Publisher 
27 Hair, J.F., Ringle, C.M., Sarstedt, M.

PLS-SEM: Indeed a silver bullet

(2011) Journal of Marketing Theory and Practice, 19 (2), pp. 139-152. Cited 6912 times.

http://www-tandfonline-com.ezlib.iium.edu.my/loi/mmtp20

doi: 10.2753/MTP1069-6679190202

View at Publisher

28 Hamid, M.A., Rahman, I.A., Halim, A.N.

Factors affecting the acceptance on Ar-Rahnu (Islamic based pawn broking): a case study of Islamic banking in Malaysia

(2014) The Macrotheme Review, 3 (4), pp. 22-35. Cited 8 times.

29 Henseler, J., Ringle, C.M., Sarstedt, M.

A new criterion for assessing discriminant validity in variance-based structural equation modeling (Open Access)

(2015) Journal of the Academy of Marketing Science, 43 (1), pp. 115-135. Cited 5456 times. http://www.springer.com.ezlib.iium.edu.my/business/journal/11747

doi: $10.1007 / \mathrm{s} 11747-014-0403-8$

View at Publisher

30 Hisham, S., Shukor, S.A., Salwa, A.B.U., Jusoff, K.

The Concept and Challenges of Islamic Pawn Broking (Ar-Rahnu)

(2013) Middle East Journal of Scientific Research, 13 (SPLISSUE), pp. 98-102. Cited 7

times.

http://www.idosi.org/mejsr/mejsrl3(cifwm)13/16.pdf

doi: 10.5829/idosi.mejsr.2013.13.1888

View at Publisher

31 Ismail, A.G., Sanusi, N.A.

A framework for regulating pawnshops: why do, what area and syariah view

(2005) Proceedings of Malaysian Finance Association (MFA)'s 7th Annual Conference, 9-10

May

Kuala Terengganu, Terengganu

32 Jacoby, J., Kaplan, L.B.

(1972) The components of perceived risk. Cited 735 times.

ACR Special Volumes

33 Jiang, Y., Wang, C.

The impact of affect on service quality and satisfaction: The moderation of service contexts

(2006) Journal of Services Marketing, 20 (4), pp. 211-218. Cited 119 times.

doi: $10.1108 / 08876040610674562$

View at Publisher

34 Kline, R.B.

(2011) Principles and Practice of Structural Equation Modelling. Cited 35594 times.

3rd ed, The Guilford Press, New York, NY

35 Lada, S., Harvey Tanakinjal, G., Amin, H.

Predicting intention to choose halal products using theory of reasoned action

(2009) International Journal of Islamic and Middle Eastern Finance and

Management, 2 (1), pp. 66-76. Cited 261 times.

http://www.emeraldgrouppublishing.com/imefm.htm

doi: 10.1108/17538390910946276

View at Publisher 
36 Lewis, B.R.

Service quality: An international comparison of bank customers' expectations and perceptions

(1991) Journal of Marketing Management, 7 (1), pp. 47-62. Cited 122 times. doi: 10.1080/0267257X.1991.9964139

View at Publisher

37 Mano, H., Oliver, R.L.

Assessing the dimensionality and structure of the consumption experience: evaluation, feeling, and satisfaction

(1993) Journal of Consumer Research, 20 (3), pp. 451-466. Cited 1854 times.

38 Mansor, N., Bashir Ahmad, S.A., Abu Bakar, S., Ismail, I.

A demographic analysis on customer acceptance towards Islamic pawn broking in malaysia (Open Access)

(2014) Asian Social Science, 10 (2), pp. 27-36. Cited 3 times.

http://www.ccsenet.org/journal/index.php/ass/article/view/33038/19123

doi: $10.5539 /$ ass.v10n2p27

View at Publisher

39 Metawa, S.A., Almossawi, M.

Banking behavior of Islamic bank customers: Perspectives and implications

(1998) International Journal of Bank Marketing, 16 (7), pp. 299-313. Cited 218 times. doi: $10.1108 / 02652329810246028$

View at Publisher

40 Mohammed, N., Daud, N.M.M., Sanusi, N.A.

Analisis Skim Ar-Rahnu: Satu Kajian Perbandingan dengan Pajak Gadai Konvensional (2005) Proceeding of Seminar Kewangan dan Ekonomi Islam: Pengukuhan dan Transformasi Ekonomi dan Kewangan Islam, 29-30 August, pp. 211-220. Cited 3 times. Esset-Bangi, Selangor Darul Ehsan

41 Montealegre, R., Keil, M.

De-escalating information technology projects: Lessons from the Denver International Airport

(2000) MIS Quarterly: Management Information Systems, 24 (3), pp. 417-443. Cited 143

times.

http://misg.org/misg/downloads/

doi: $10.2307 / 3250968$

View at Publisher

42 Newman, K.

Interrogating SERVQUAL: A critical assessment of service quality measurement in a high street retail bank

(2001) International Journal of Bank Marketing, 19 (3), pp. 126-139. Cited 183 times. doi: $10.1108 / 02652320110388559$

View at Publisher

43 Oliver, R.L.

Cognitive, affective, and attribute bases of the satisfaction response

(1993) Journal of Consumer Research, 20 (3), pp. 418-430. Cited 1854 times.

44 Oliver, R.L.

(1997) Satisfaction: A Behavioral Perspective on the Consumer. Cited 5332 times.

McGraw-Hill, New York, NY 
45 Chau, P.Y.K., Hu, P.J.

Examining a model of information technology acceptance by individual professionals: An exploratory study

(2002) Journal of Management Information Systems, 18 (4), pp. 191-229. Cited 374 times. doi: 10.1080/07421222.2002.11045699

View at Publisher

46 Pavlou, P.A.

Consumer acceptance of electronic commerce: Integrating trust and risk with the technology acceptance model

(2003) International Journal of Electronic Commerce, 7 (3), pp. 101-134. Cited 2764 times. http://www-tandfonline-com.ezlib.iium.edu.my/toc/mjec20/current doi: 10.1080/10864415.2003.11044275

View at Publisher

47 Pavlou, P.A.

Consumer acceptance of electronic commerce: Integrating trust and risk with the technology acceptance model

(2003) International Journal of Electronic Commerce, 7 (3), pp. 101-134. Cited 2764 times. http://www-tandfonline-com.ezlib.iium.edu.my/toc/mjec20/current doi: 10.1080/10864415.2003.11044275

View at Publisher

48 Pavlou, P.A.

Integrating trust in electronic commerce with the technology acceptance model: model development and validation

(2001) Proceedings of the 7th Americas Conference on Information Systems. Cited 155

times.

Boston, MA

49 Peter, J.P., Ryan, M.J.

An investigation of perceived risk at the brand level

(1976) Journal of Marketing Research, 13 (2), pp. 184-188. Cited 344 times.

50 Peter, J.P., Tarpey, L.X.

A comparative analysis of three consumer decision strategies

(1975) Journal of Consumer Research, 2 (1), pp. 29-37. Cited 316 times.

51 Ramayah, T.

Interface Characteristics, Perceived Ease of Use and Intention to Use an Online Library in Malaysia

(2006) Information Development, 22 (2), pp. 123-133. Cited 62 times. doi: $10.1177 / 0266666906065575$

View at Publisher

52 Ramayah, T., Ling, N.S., Taghizadeh, S.K., Rahman, S.A.

Factors influencing SMEs website continuance intention in Malaysia

(2016) Telematics and Informatics, 33 (1), art. no. 693, pp. 150-164. Cited 79 times. doi: 10.1016/j.tele.2015.06.007

View at Publisher

53 Ramayah, T., Siron, R., Dahlan, N., Mohamad, O.

Technology usage among owners/managers of SME's: the role of demographic and motivational variables

(2002) The proceedings of the 6th Annual Asian-Pacific Forum for Small Business on Small and Medium Enterprises Linkages, Networking and Clustering. Cited 13 times. 
54 Sam, M.F.M., Tahir, M.N.H., Abdul Latif, N.K.

The awareness and the acceptance of islamic pawnshops

(2010) International Journal of Research and Reviews in Applied Sciences, 2 (2). Cited 5

times.

55 Schepers, J., Wetzels, M.

A meta-analysis of the technology acceptance model: Investigating subjective norm and moderation effects

(2007) Information and Management, 44 (1), pp. 90-103. Cited 858 times.

doi: 10.1016/j.im.2006.10.007

View at Publisher

56 Setyohadi, D.B., Aristian, M., Sinaga, B.L., Hamid, N.A.A.

Social critical factors affecting intentions and behaviours to use E-

Learning: An empirical investigation using technology acceptance model (Open Access)

(2017) Asian Journal of Scientific Research, 10 (4), pp. 271-280. Cited 9 times.

http://docsdrive.com/pdfs/ansinet/ajsr/2017/271-280.pdf

doi: 10.3923/ajsr.2017.271.280

View at Publisher

57 Taib, F.M., Ramayah, T., Abdul Razak, D.

Factors influencing intention to use diminishing partnership home financing

(2008) International Journal of Islamic and Middle Eastern Finance and

Management, 1 (3), pp. 235-248. Cited 107 times.

http://www.emeraldgrouppublishing.com/imefm.htm

doi: $10.1108 / 17538390810901168$

View at Publisher

58 Taylor, S., Todd, P.

Decomposition and crossover effects in the theory of planned behavior: A study of consumer adoption intentions

(1995) International Journal of Research in Marketing, 12 (2), pp. 137-155. Cited 661 times. doi: 10.1016/0167-8116(94)00019-K

View at Publisher

59 Teo, T., Milutinović, V., Zhou, M.

Modelling Serbian pre-service teachers' attitudes towards computer use: A SEM and MIMIC approach

(2016) Computers and Education, 94, pp. 77-88. Cited 37 times.

http://www.journals.elsevier.com/computers-and-education/

doi: 10.1016/j.compedu.2015.10.022

View at Publisher

60 Thaker, H.M.T., Khaliq, A., Thaker, M.A.M.T.

Evaluating the service quality of Malaysian Islamic banks: an importance-performance

analysis approach

(2016) International Journal of Business and Information, 11 (3), p. 341 . Cited 9 times.

61 Thakur, R., Srivastava, M.

Adoption readiness, personal innovativeness, perceived risk and usage intention across customer groups for mobile payment services in India

(2014) Internet Research, 24 (3), pp. 369-392. Cited 246 times. doi: 10.1108/IntR-12-2012-0244

View at Publisher 
62 Venkatesh, V., Morris, M.G., Davis, G.B., Davis, F.D.

User acceptance of information technology: Toward a unified view

(2003) MIS Quarterly: Management Information Systems, 27 (3), pp. 425-478. Cited 16368

times.

http://misq.org/misq/downloads/

doi: $10.2307 / 30036540$

View at Publisher

63 Westbrook, R.A.

Product/consumption-based affective responses and post purchase process

(1987) Journal of Marketing Research, 24 (3), pp. 258-270. Cited 1221 times.

64 Wirtz, J., Bateson, J.E.G.

Consumer satisfaction with services: Integrating the environment perspective in services marketing into the traditional disconfirmation paradigm

(1999) Journal of Business Research, 44 (1), pp. 55-66. Cited 265 times.

http://www.elsevier.com.ezlib.iium.edu.my/locate/jbusres

doi: 10.1016/S0148-2963(97)00178-1

View at Publisher

65 Yan, Z., Wang, T., Chen, Y., Zhang, H.

Knowledge sharing in online health communities: A social exchange theory perspective

(2016) Information and Management, 53 (5), pp. 643-653. Cited 213 times.

doi: 10.1016/j.im.2016.02.001

View at Publisher

66 Al-Shafi, S.H.

(2009) Factors Affecting e-Government Implementation and Adoption in the State of

Qatar. Cited 15 times.

Brunel University, West London

67 Cronin, J.J., Taylor, S.A.

Measuring service quality: a re-examination and extension

(1992) Journal of Marketing, 56 (3), pp. 55-68. Cited 5337 times.

68 Davis, F.D.

Perceived usefulness, perceived ease of use, and user acceptance of information technology

(1989) MIS Quarterly: Management Information Systems, 13 (3), pp. 319-339. Cited 25176

times.

http://misq.org/misg/downloads/

doi: $10.2307 / 249008$

View at Publisher

69 Othman, A., Owen, L.

Adopting and measuring customer service quality (SQ) in Islamic banks: a case study in

Kuwait finance house

(2001) International Journal of Islamic Financial Services, 3 (1), pp. 1-26. Cited 168 times.

70 Paul, K.J., Musa, M., Nansubuga, A.K.

Facilitating condition for e-learning adoption - case of Ugandan universities

(2015) Journal of Communication and Computer, 12 (4), pp. 244-249. Cited 9 times.

Mohd Thas Thaker, H.; Department of Economics and Finance, Sunway University, Selangor,

Malaysia; email:hassanudint@sunway.edu.my

(C) Copyright 2021 Elsevier B.V., All rights reserved. 


\section{About Scopus}

What is Scopus

Content coverage

Scopus blog

Scopus API

Privacy matters

\section{Language}

日本語に切り替える

切换到简体中文

切換到繁體中文

Русский язык

\section{Customer Service}

Help

Contact us

ELSEVIER

Terms and conditions $\pi$ Privacy policy $\pi$

Copyright @ Elsevier B.V ז. All rights reserved. Scopus ${ }^{\circledR}$ is a registered trademark of Elsevier B.V.

We use cookies to help provide and enhance our service and tailor content. By continuing, you agree to the use of cookies.

Q RELX 